\title{
The potential roles of aluminum chloride and sodium fluoride on the neurotoxicity of the cerebral cortex, hippocampus, and hypothalamus of male rat offspring
}

\author{
Amal A. Kinawy iD
}

\begin{abstract}
Background: This study highlights the potential toxic effects of aluminum chloride and sodium fluoride (NaF), given to pregnant female rats, on the development of the brain neurotransmission systems in their offspring. Pregnant female rats received a daily dose of $\mathrm{NaF}(0.15 \mathrm{~g} / \mathrm{L})$ or $\mathrm{AlCl}_{3}(0.5 \mathrm{~g} / \mathrm{L})$ in the drinking deionized water, either separately or in combination with each other, starting from the 6th day of gestation till the end of the breastfeeding period. After weaning, the male offspring were divided into two subgroups; in the first one, the offspring continued to have the same treatments in their drinking water at the same dose levels, as were provided to the mothers, until the age of 70 days of postnatal life. In the second subgroup, the pups were provided with a drinking deionized water without the treatments for a similar period of time. At the end of the experimental period, the contents of the brain monoamine neurotransmitters, as well as the acetylcholinesterase (AChE) activity, were assessed in the cerebral cortex, hippocampus, and hypothalamus. In addition, the offspring were subjected to the exploratory behavioral test.

Results: The results revealed that sodium fluoride and aluminum chloride induced sever perturbation and imbalance in the neurotransmission systems under investigation. The pattern of change and severity differed with the different brain areas. The combination of the two pollutants exerted general synergistic impacts with different specific response in the different brain area.

Conclusion: It is concluded from this study that the exposure to sodium fluoride and aluminum chloride, either separately or in combination, induced profound disturbances in the transmission within the rat brain monoamine systems and subsequent undesirable impact on the animal's behavioral aspects.
\end{abstract}

Keywords: Sodium fluoride, Aluminum chloride, Prenatal and postnatal stages, Monoamines, AChE activity, Exploratory behavior

\section{Background}

The abundance of aluminum and fluoride in nature and their excessive use in industry and health products have made the exposure to these elements unavoidable. The exposure for the general population is mainly through oral intake and the major sources are the drinking water, tea, soil, residues in food products, cooking utensils, as well as in aluminum- or fluoride-containing medications (Fan, Gao, Wang, Gong, Guo, \& Zhao, 2016; Kinawy \&

Correspondence: aa_behphys2002@yahoo.com

Biology Department, Faculty of Science, Taif University, Taif 5700, Kingdom of Saudi Arabia (c) The Author(s). 2019 Open Access This article is distributed under the terms of the Creative Commons Attribution 4.0 International License (http://creativecommons.org/licenses/by/4.0/), which permits unrestricted use, distribution, and reproduction in any medium, provided you give appropriate credit to the original author(s) and the source, provide a link to the Creative Commons license, and indicate if changes were made.
Al-Eidan, 2018; Kinawy \& Ezzat, 2013). Aluminum and fluoride are among the most common neurotoxicants which induce disturbances in the nervous system and consequently on the behavior (Choi, Sun, Zhang, \& Grandjean, 2012; Xiang, Liang, Chen, Wang, Chen, \& Chen, 2003). Excessive exposure to fluorine through prenatal and postnatal stages of development induced perturbation in the homeostasis of the central nervous system (Dec, Łukomska, Maciejewska, Jakubczyk, Baranowska-Bosiacka, Chlubek, \& Gutowska, 2017). The noxious effects of fluorine are attributed to its ability to cross the placental and blood-brain barrier which leads 
to its absorption and accumulation in different brain regions. This will lead to cerebral damage and appearance of neurological disorders later in life (Saunders, Liddelow, \& Dziegielewska, 2012).

Aluminum easily enters most brain regions of the rats and the highest aluminum concentrations were found in young developing rats. This shows that the early stages of life is crucial for brain aluminum accumulation (Abu-Taweel, Ajarem, \& Ahmad, 2012; Domingo et al., 1996; Dórea, 2015; Golub \& Domingo, 1997). Moreover, exposure to aluminum, particularly in utero or during the early postnatal life, contributes to serious brain disturbances in neurotransmission essential for brain higher functions as well as in sensory-motor processing. The study of the impact of exposure to aluminum in newly born organisms is of a particular interest because of the possible devastating, and commonly irreversible and life-time long persistence. The profound effects of neurotoxins on the young animals is attributed to the fact that the metabolic pathways, biotransformation and elimination mechanisms, gut and renal functions, neural development, and particularly brain barrier formation are not fully developed yet in young animals. On the other hand, some pathologic changes which do not appear by exposure to aluminum separately arise when it combines with fluoride (Ge, Xie, Zhang, Tan, Wan, Wang, \& Jin, 2018; Kaur, Bijarnia, \& Nehru, 2009; Strunecká, 1999).

Several epidemiologic studies have demonstrated an association between fluoride and aluminum, administered separately or in combination, and neurobehavioral deterioration in populations living in regions with endemic environmental pollution (Akinrinade, Memudu, \& Ogundele, 2015; Kraus \& Forbes, 1992; Varner, Jensen, Horvath, \& Isaacson, 1998; Yazdi, Sharifian, DehghaniBeshne, Momeni, \& Aminian, 2011). The association between long-term aluminum and fluoride or aluminum/ fluoride intake in the drinking water and the development of Alzheimer's disease has been suggested (Belojevic \& Jakovljevic, 1998; Ge et al., 2018; Zhu et al., 2016). Aluminum and fluoride have been found to induce severe perturbation in the monoamines neurotransmitters, particularly norepinephrine and dopamine, by increasing their oxidation with the monoamine oxidase which leads to production of toxic aldehyde metabolites and precursors of oxidative stress. It is worth mentioning that the accumulation of aldehyde metabolites was reported in the brains of the patients with Alzheimer's and Parkinson's diseases (Burke et al., 2004; Grima, Benz, Parpura, Cuénod, \& Do, 2003). In addition, the potential toxic effect of aluminum and fluoride may include disruption in serotonergic neurotransmission throughout the entire brain regions (Kaur, Bijarnia, \& Nehru, 2009; Kumar, 2002). Zheng and Liang (1998) suggested that the depletion of dopaminergic and cholinergic transmitters in the central nervous system might play a central role in $\mathrm{Al}$-induced neurotoxicity. On the other hand, $\mathrm{Al}$ exposure led to a significant decrease in the acetylcholinesterase activity in the brain and, as consequence, induced disturbances in a cholinergic neurotransmission (Ravi, Prabhu, Raju, \& Bindu, 2000; Zatta, Ibn-Lkhayat-Idrissi, Zambenedetti, Kilyen, \& Kiss, 2002). Moreover, other researchers reported an interaction between $\mathrm{Al}$ and the cholinergic system which resulted in increased acetylcholinesterase (AChE) activity in rodents (Kumar, 2002; Taïr, Kharoubi, Taïr, Hellal, \& Benyettou, 2016; Thirunavukkarasu, Venkataraman, Raja, \& Upadhyay, 2012; Yellamma, Saraswathamma, \& Kumari, 2010).

\section{The aim of the work}

The present work was initiated in order to evaluate the impact of aluminum and fluoride intake through the drinking water, during the prenatal and postnatal life, on the contents of the monoamines and acetylcholinesterase activity in different brain regions. Additionally, the impact on the exploratory behavior was also assessed.

\section{Materials and methods \\ Experimental animals}

Healthy adult female rat mothers, with an average weight of $180 \pm 15 \mathrm{~g}$, were used. The rats were obtained from the animal house of the Faculty of Science, Dammam University and housed individually in plastic cages at $20{ }^{\circ} \mathrm{C}$ and $12 \mathrm{~h}$ light $/ 12 \mathrm{~h}$ dark cycle. The handling and use of the animals were strictly in agreement with the regulations and guidelines on the practice embraced by the ethics committees for use of animals for research.

\section{Chemicals}

Aluminum chloride CAS Number 7446-70-0 $\left(\mathrm{AlCl}_{3}\right)$ and sodium fluoride CAS Number 7681-49-4 (NaF) with 99\% purity were purchased from Sigma-Aldrich is now Merck in USA. All chemicals used for the HPLC analyses employed for the estimation of the monoamines (Epinephrine -CAS Number: 51-43-4; Norepinephrine: CAS Number 51-41-2; Serotonin: CAS Number: 50-67-9; Dopamine CAS Number: 62-31-7) as well as those used for the QuantiChrom AChE (DACE-100) assay kits required to measure the activity of acetylcholinesterase (AChE) were also purchased from Sigma-Aldrich Company.

\section{Experimental design}

In order to obtain the offspring male rats, 100 female mothers were mated with males ( 1 male/5 females) of the same strain. The vaginal smears were examined to detect the period of positive estrus, according to the 
method of Harkness and Wagner (1983). The number of pregnant females was 80 rats, after day 6 of gestation; the pregnant rats were randomly divided into 4 groups $\mathrm{A}, \mathrm{B}, \mathrm{C}$, and $\mathrm{D}$. The daily treatments were deionized drinking water, $0.15 \mathrm{~g}$ sodium fluoride $(\mathrm{NaF}, 0.15 \mathrm{~g} / \mathrm{L}$ added to the drinking deionized water) according to $\mathrm{He}$ and Chen (2006), $0.5 \mathrm{~g}$ aluminum chloride $\left(\mathrm{AlCl}_{3}, 0.5 \mathrm{~g} /\right.$ $\mathrm{L}$ added to the drinking deionized water) according to Fulton and Jeffery (1990), and a combination of aluminum and fluoride with the same concentrations added to the drinking deionized water, respectively. The treatment was supplied daily in the drinking water throughout the pregnancy, postpartum, and weaning periods. After weaning, the male newly born rats were separated from the females in each group. According to the G-power analysis, the total sample size required for the present experimental design was 196 males of the newly born rats. From group A, 28 rats were taken and assigned as group 1. Males in group B were subdivided into groups II and III, group C into groups IV and V, and group D into groups VI and VII, each with sample size of 28 males. Throughout 70 days of postnatal stage, the born males in the group I, III, V, and VII were supplied daily with drinking deionized water. Meanwhile, the males in groups II, IV, and VI were daily supplied with $\mathrm{NaF}(0.15 \mathrm{~g} / \mathrm{L}$ of deionized drinking water $)$ or $\mathrm{AlCl}_{3}$ $(0.5 \mathrm{~g} / \mathrm{L}$ of deionized drinking water $)$ separately or in combination, respectively (Table 1).

\section{Sampling}

Seventy days post-administration of treatments, as shown in Table 1, $20(\mathrm{n} 1=20)$ and $8(\mathrm{n} 2=8)$ males were withdrawn from each group to run the exploratory behavior tests (object investigation) and the measurements of neurotransmitters and acetylcholinesterase activity, respectively (Table 1). Rats were scarified and the brain was quickly excised and dissected on an ice plate to obtain the cerebral cortex, hippocampus, and hypothalamus. The tissues were stored at $-80{ }^{\circ} \mathrm{C}$ pending

Table 1 Experimental design to illustrate the experimental subgroups of the post-weaning male offspring

\begin{tabular}{|c|c|c|c|c|c|c|c|}
\hline \multirow[t]{2}{*}{ Sources } & \multicolumn{7}{|c|}{ Experimental groups } \\
\hline & I & $\|$ & III & IV & V & $\mathrm{Vl}$ & VII \\
\hline DW & Ok & No & Ok & No & Ok & No & Ok \\
\hline $\mathrm{NaF}(\mathrm{g} / \mathrm{L})$ & No & $0.15 \mathrm{~g}^{\mathrm{a}}$ & No & No & No & $0.15 \mathrm{~g}^{\mathrm{a}}$ & No \\
\hline $\mathrm{AlCl3}(\mathrm{g} / \mathrm{L})$ & No & No & No & $0.5 \mathrm{~g}^{\mathrm{a}}$ & No & $0.5 \mathrm{~g}^{\mathrm{a}}$ & No \\
\hline Sample size ${ }^{(\mathrm{n} 1)}$ & 20 & 20 & 20 & 20 & 20 & 20 & 20 \\
\hline Sample size ${ }^{(n 2)}$ & 8 & 8 & 8 & 8 & 8 & 8 & 8 \\
\hline Sampling time & \multicolumn{7}{|c|}{70 days post-administration } \\
\hline
\end{tabular}

$D W$ deionized water, $g / L$ gram dissolved in $1 \mathrm{~L}$

${ }^{n 1}$ and $^{n 2}$ : Sample size of males required for the behavior and neurotransmitters experimentation

${ }^{\mathrm{a}}$ The doses of $\mathrm{NaF}$ or $\mathrm{AlCl}_{3}$ dissolved in $1 \mathrm{~L}$ deionized water analyses. The levels of monoamines (epinephrine, norepinephrine, dopamine, and serotonin) as well as acetylcholinesterase activity were then estimated in the three brain regions.

\section{Exploratory behavior test (object investigation)}

In this test, a task was conducted by each rat as a measure of exploratory behavior, according to the method described by Aitken (1974). Each one of the 20 rats was tested for a 5 -min period daily for 5 consecutive days. A novel object was placed in the center of the field (rubber tube, steel chains, or crumpled paper balls). For each test, a rat was placed in a corner, and the number of approaches (number of times the nose came within one inch or touched the objects) was recorded along with the time (duration) spent with the nose touching the objects.

\section{Monoamines assay}

The levels of monoamines (epinephrine, norepinephrine, dopamine, and serotonin) in the brain regions (the cerebral cortex, hippocampus, and hypothalamus) were estimated by the reversed-phase high-performance liquid chromatographic (RP-HPLC), according to the method described by Pagel, Blome, and Wolf (2000). An accurate weight of the cerebral cortex, hippocampus, and hypothalamus was homogenized in $1 / 10 w / v$ of $75 \%$ aqueous HPLC grade methanol. The homogenate was spun at $6000 \mathrm{r} / \mathrm{min}$ for $10 \mathrm{~min}$, and the produced supernatant was used for the estimation of monoamines neurotransmitters using an internal standard for each type. The supernatant was immediately extracted from the trace elements and lipids by the use of solid-phase extraction CHROMABOND column NH2 phase, Cat. No. 730031. An amount of $20 \mu \mathrm{l}$ of supernatant was injected into an AQUA column for separation of catecholamines, UV $270 \mathrm{~nm}$. The concentrations of measured monoamines were expressed as micrograms per gram of tissue $(\mu \mathrm{g} / \mathrm{g})$.

\section{Acetylcholine esterase activity}

AChE activity was assayed calorimetrically using QuantiChrom AChE (DACE-100) assay kits, according to the method described by Kovarik et al. (2003). The sample was prepared by brief homogenization of an exact weight of each studied brain region in cold $0.1 \mathrm{M}$ phosphate buffer ( $\mathrm{pH} 7.5)$ followed by centrifugation at $14,00 \mathrm{r} / \mathrm{min}$ for $5 \mathrm{~min}$. The obtained supernatant was used for the assay. In the AChE assay, the thiocholine produced by the action of AChE formed a yellow color with 5,5-dithiobis (2-nitrobenzoic acid). The intensity of the produced color, measured at $412 \mathrm{~nm}$, is directly proportional to the AChE activity in the sample. AChE activity was expressed as micromoles of acetylthiocholine 
hydrolyzed per minute per gram of protein $(\mathrm{mmol} \mathrm{SH} /$ $\mathrm{g} / \mathrm{min}$ ).

\section{Statistical analysis}

Kolmogorov-Smirnov test indicated that the present data were normally distributed, and therefore the parametric statistical analyses (ANOVA) were applied. One-way ANOVA was used and followed by the least significant different test (LSD), that is similar to $t$ distribution analysis to compare between every two groups. Data were presented as a mean of eight male rats \pm standard error of mean (SEM). The significant difference was computed at $\alpha=0.05(P<0.05)$. Statistical analysis of the present data was analyzed by the aid of the IBM Statistical Package for the Social Sciences, SPSS version 24.

\section{Results}

\section{Exploratory behavior test (object investigation)}

The male rats which were administered the fluoride (group II) or aluminum (group IV) alone or in combination (group VI) throughout the prenatal and postnatal periods up to day 70 exhibited a significant decrease in the number of approaches and possessed a longer time spent touching the object in comparison with rats given only deionized water (group I) throughout all the five consecutive days of the test. The groups which were given aluminum or fluoride until after the weaning stage were not significantly different from group I or from each other on the first to the fifth day of the test. The number of approaches in the group treated with the combined doses were lower than that of group I on the fourth and fifth days, whereas the time of approaches was higher than that of group III on the first day and from group $\mathrm{V}$ on the second day (Tables 1 and 2).

\section{Monoamines levels in brain areas}

In the cerebral cortex, no statistical differences in the levels of norepinephrine, epinephrine, dopamine, and serotonin were found in groups II and III when compared with group I, except in the case of serotonin in group II which was significantly lower than that of group I. The levels of dopamine, epinephrine, and norepinephrine in group IV were significantly increased as a result of $\mathrm{Al}$ intake during the pre- and postnatal periods, whereas the level of serotonin was markedly decreased and was lower than its level in the cerebral cortex of group I (Table 4). The levels of norepinephrine and dopamine were significantly higher than those of the control, $\mathrm{NaF}$, and $\mathrm{AlCl}_{3}+\mathrm{H}_{2} \mathrm{O}$-treated values; meanwhile, dopamine was significantly higher in comparison with the other six experimental groups. On the contrary, epinephrine and serotonin levels were significantly decreased in response to $\mathrm{NaF}+\mathrm{AlCl}_{3}$ intake in comparison with the control, $\mathrm{NaF}+\mathrm{H}_{2} \mathrm{O}, \mathrm{AlCl}_{3}+\mathrm{H}_{2} \mathrm{O}$ groups. The intake of $\mathrm{NaF}+\mathrm{AlCl}_{3}+\mathrm{H}_{2} \mathrm{O}$ induced a significant decrease in norepinephrine as compared with the groups that were supplied with $\mathrm{NaF}, \mathrm{NaF}+\mathrm{H}_{2} \mathrm{O}, \mathrm{AlCl}_{3}$, and $\mathrm{NaF}+\mathrm{AlCl}_{3}$, but these values were not significantly different from those of the corresponding controls values, except on the case of epinephrine level which exhibited a lower value than those of the control, $\mathrm{NaF}+\mathrm{H}_{2} \mathrm{O}$, $\mathrm{AlCl}_{3}, \mathrm{AlCl}_{3}+\mathrm{H}_{2} \mathrm{O}$-treated groups. The dopamine level in the $\mathrm{NaF}+\mathrm{AlCl}_{3}+\mathrm{H}_{2} \mathrm{O}$-treated group was higher than those of the control, $\mathrm{NaF}, \mathrm{NaF}+\mathrm{H}_{2} \mathrm{O}, \mathrm{AlCl}_{3}, \mathrm{AlCl}_{3}$ $+\mathrm{H}_{2} \mathrm{O}$-treated groups, but lower than the $\mathrm{NaF}+\mathrm{AlCl}_{3}$ group (Table 1).

In the hippocampus, the levels of norepinephrine and epinephrine were significantly increased in all groups after the intake of aluminum and fluoride except in the groups treated with $\mathrm{NaF}, \mathrm{NaF}+\mathrm{H}_{2} \mathrm{O}$, and $\mathrm{AlCl}_{3}+\mathrm{H}_{2} \mathrm{O}$ where epinephrine did not reveal any significant change when comparisons were made with the corresponding control. On the contrary, dopamine and serotonin were significantly reduced with the treatments in comparison with the control, but the level of serotonin in the $\mathrm{NaF}+$ $\mathrm{H}_{2} \mathrm{O}$-treated rats was not significantly different from those of the control or NaF-treated values. With respect to epinephrine, the magnitude of increase was significantly higher with the $\mathrm{NaF}$ plus $\mathrm{AlCl}_{3}$ in comparison with all other treated groups. The value in the $\mathrm{NaF}+$

Table 2 The exploratory learning (the number of approaches) in the male offspring of groups I to VII, 70 days postnatal. Data are presented as a mean of eight rats \pm SEM

\begin{tabular}{|c|c|c|c|c|c|}
\hline \multirow{2}{*}{$\begin{array}{l}\text { Experimental } \\
\text { groups }\end{array}$} & \multicolumn{5}{|c|}{ Number of approaches } \\
\hline & 1 day & 2 days & 3 days & 4 days & 5 days \\
\hline Group I & $3.1 \pm 0.23$ & $4.5 \pm 0.21$ & $5.1 \pm 0.20$ & $7.1 \pm 0.23$ & $6.85 \pm 0.32$ \\
\hline Group II & $2.3 \pm 0.21^{\mathrm{a}}$ & $2.6 \pm 0.22^{\mathrm{a}}$ & $3.3 \pm 0.31^{\mathrm{a}}$ & $3.45 \pm 0.198^{\mathrm{a}}$ & $3.8 \pm 0.26^{a}$ \\
\hline Group III & $3.5 \pm 0.25^{b}$ & $4.35 \pm 0.27^{b}$ & $5.05 \pm 0.31^{b}$ & $6.45 \pm 0.34^{b}$ & $6.35 \pm 0.28^{b}$ \\
\hline Group IV & $2.4 \pm 0.22^{\mathrm{ac}}$ & $3 \pm 0.23^{\mathrm{ac}}$ & $3.6 \pm 0.2^{\mathrm{ac}}$ & $3.95 \pm 0.276^{\mathrm{ac}}$ & $3.6 \pm 0.35^{\mathrm{ac}}$ \\
\hline Group V & $3.4 \pm 0.26^{\mathrm{bd}}$ & $4.25 \pm 0.25^{\mathrm{bd}}$ & $5.55 \pm 0.35^{\text {bd }}$ & $6.4 \pm 0.31^{b d}$ & $6.65 \pm 0.32^{\mathrm{bd}}$ \\
\hline Group VI & $2.3 \pm 0.21^{\text {ace }}$ & $2.65 \pm 0.23^{\text {ace }}$ & $2.8 \pm 0.28^{\text {ace }}$ & $3.05 \pm 0.266^{\text {acde }}$ & $3.3 \pm 0.27^{\text {ace }}$ \\
\hline Group VII & $3.65 \pm 0.25^{\mathrm{bdf}}$ & $4.2 \pm 0.24^{\mathrm{bdf}}$ & $5.7 \pm 0.36^{\text {bdf }}$ & $6.15 \pm 0.315^{\mathrm{abdf}}$ & $5.9 \pm 0.38^{\mathrm{abdf}}$ \\
\hline
\end{tabular}

a, b, c, d, e, f: Significant difference in comparison with the group I, II, III, IV, V, VI, and VII, at $\mathrm{a}=0.05(P<0.05)$, respectively 
$\mathrm{AlCl}_{3}+\mathrm{H}_{2} \mathrm{O}$ value was higher than those of the control, $\mathrm{NaF}+\mathrm{H}_{2} \mathrm{O}$, and $\mathrm{AlCl} 3+\mathrm{H}_{2} \mathrm{O}$ treatments (Table 2).

Table 3 shows that the levels of norepinephrine in most groups treated with the substances under investigation revealed a significant increase above the control values, except with the $\mathrm{NaF}$ treatment, which caused a significant decrease from all other groups. The level with the $\mathrm{NaF}+\mathrm{H}_{2} \mathrm{O}$ treatment was less than those of the $\mathrm{AlCl}_{3}$ and $\mathrm{AlCl}_{3}+\mathrm{H}_{2} \mathrm{O}$, but did not reveal any statistical change from the control, $\mathrm{NaF}+\mathrm{AlCl}_{3}, \mathrm{NaF}+\mathrm{AlCl}_{3}+$ $\mathrm{H}_{2} \mathrm{O}$ values. The levels of epinephrine in $\mathrm{NaF}$ and $\mathrm{NaF}+$ $\mathrm{AlCl}_{3}+\mathrm{H} 2 \mathrm{O}$-treated groups revealed no statistical difference from those in the control and $\mathrm{NaF}+\mathrm{AlCl}_{3}+$ $\mathrm{H}_{2} \mathrm{O}$ groups. Meanwhile, the norepinephrine (NE) level in the $\mathrm{NaF}+\mathrm{H}_{2} \mathrm{O}$-treated group was significantly higher than that of the $\mathrm{NaF}$, but less than those of $\mathrm{AlCl}_{3}$ and $\mathrm{NaF}+\mathrm{AlCl}_{3}$-treated groups. The $\mathrm{NE}$ level in the $\mathrm{AlCl}_{3}+$ $\mathrm{H}_{2} \mathrm{O}$-treated group was less than its levels in both $\mathrm{AlCl}_{3}$ and $\mathrm{NaF}+\mathrm{AlCl}_{3}$-treated groups. The $\mathrm{NE}$ in the $\mathrm{NaF}+$ $\mathrm{AlCl}_{3}$ group was significantly higher than all other experimental groups, except in case of the $\mathrm{AlCl}_{3}$ treatment, where there was no significant difference. The levels of dopamine with all treatments were significantly less than those of the corresponding control values. The NaF intake induced a significant decrease in dopamine (DA) when compared with its levels in the $\mathrm{NaF}+\mathrm{H}_{2} \mathrm{O}, \mathrm{AlCl}_{3}$ $+\mathrm{H}_{2} \mathrm{O}$, and $\mathrm{NaF}+\mathrm{AlCl}_{3}+\mathrm{H}_{2} \mathrm{O}$-treated groups. However, the $\mathrm{Da}$ level in the $\mathrm{NaF}$ group did not reveal any significant change from the $\mathrm{AlCl}_{3}$ and $\mathrm{NaF}+\mathrm{AlCl}_{3}$ groups. The DA level in the $\mathrm{NaF}+\mathrm{H}_{2} \mathrm{O}$ group was significantly higher than its levels in the groups treated with $\mathrm{AlCl}_{3}$ or $\mathrm{NaF}+\mathrm{AlCl}_{3}$, but no statistical difference was found between $\mathrm{NaF}+\mathrm{H}_{2} \mathrm{O}$ and $\mathrm{NaF}+\mathrm{AlCl}_{3}+$ $\mathrm{H} 2 \mathrm{O}$-treated groups. $\mathrm{AlCl}_{3}$-exposed rats exhibited a significant increase in comparison to $\mathrm{AlCl}_{3}+\mathrm{H} 2 \mathrm{O}$ and $\mathrm{NaF}+\mathrm{AlCl}_{3}+\mathrm{H} 2 \mathrm{O}$. The $\mathrm{NaF}+\mathrm{AlCl}_{3}$ group exhibited a significant increase when compared with $\mathrm{AlCl}_{3}+\mathrm{H}_{2} \mathrm{O}$ or $\mathrm{NaF}+\mathrm{AlCl}_{3}+\mathrm{H}_{2} \mathrm{O}$ values. Serotonin level was reduced in the $\mathrm{NaF}, \mathrm{AlCl}_{3}, \mathrm{NaF}+\mathrm{AlCl}_{3}$, and $\mathrm{NaF}+\mathrm{AlCl}_{3}$ $+\mathrm{H}_{2} \mathrm{O}$ groups in comparison with the corresponding control values, also the $\mathrm{NaF}$ value was less than those in the $\mathrm{NaF}+\mathrm{H}_{2} \mathrm{O}, \mathrm{AlCl}_{3}, \mathrm{AlCl}_{3}+\mathrm{H}_{2} \mathrm{O}$, and $\mathrm{NaF}+\mathrm{AlCl}_{3}+$ $\mathrm{H}_{2} \mathrm{O}$ groups, but no statistical change was detected between the $\mathrm{NaF}$ and $\mathrm{NaF}+\mathrm{AlCl}_{3}$ groups. The level in the $\mathrm{NaF}+\mathrm{H}_{2} \mathrm{O}$ group was significantly elevated above those in the $\mathrm{AlCl}_{3}, \mathrm{NaF}+\mathrm{AlCl}_{3}$, and $\mathrm{NaF}+\mathrm{AlCl}_{3}+$ $\mathrm{H}_{2}$ Ogroups, but $\mathrm{NaF}+\mathrm{H}_{2} \mathrm{O}$ and $\mathrm{AlCl}_{3}+\mathrm{H}_{2} \mathrm{O}$ did not reveal any significant change from the control values, $\mathrm{AlCl}_{3}+\mathrm{H}_{2} \mathrm{O}$ treatment had a significant increase above the values recorded for the $\mathrm{NaF}+\mathrm{AlCl}_{3}$ and $\mathrm{NaF}+$ $\mathrm{AlCl}_{3}+\mathrm{H}_{2} \mathrm{O}$ treatments.

Data presented in Table 4 show that the rats administered $\mathrm{NaF}, \mathrm{AlCl}_{3}$, and $\mathrm{NaF}+\mathrm{AlCl}_{3}$ exhibited a decrease in the content of $\mathrm{AChE}$ in the cerebral cortex and hippocampus in comparison with the control group. Moreover, in the hypothalamus, the level was significantly reduced in all groups when compared to the control group, except in the $\mathrm{NaF}+\mathrm{H}_{2} \mathrm{O}$ which did not reveal any significant change from the control group. In the cerebral cortex, NaF-treated group did not reveal a significant change in comparison with $\mathrm{NaF}+\mathrm{H}_{2} \mathrm{O}$ and $\mathrm{AlCl}_{3}$, but the activity in the $\mathrm{NaF}$ group in the hippocampus and hypothalamus was less than that of $\mathrm{NaF}+$ $\mathrm{H}_{2} \mathrm{O}$ and less than both $\mathrm{AlCl}_{3}+\mathrm{H}_{2} \mathrm{O}$ and $\mathrm{NaF}+\mathrm{AlCl}_{3}+$ $\mathrm{H}_{2} \mathrm{O}$ in all brain regions. The $\mathrm{NaF}+\mathrm{AlCl}_{3}$ treatment resulted in a significant decrease when comparison was made with the $\mathrm{NaF}+\mathrm{H}_{2} \mathrm{O}, \mathrm{AlCl}_{3}+\mathrm{H}_{2} \mathrm{O}$, and $\mathrm{NaF}+$ $\mathrm{AlCl}_{3}+\mathrm{H}_{2} \mathrm{O}$. The enzyme activity in the $\mathrm{NaF}+\mathrm{AlCl}_{3}+$ $\mathrm{H}_{2} \mathrm{O}$ group was higher than that in the $\mathrm{AlCl}_{3}$, but did not reveal any significant change from the control in the cerebral cortex and hippocampus. In the hypothalamus, the enzyme activity was significantly less than the corresponding control group (Tables 5, 6, and 7).

\section{Discussion}

This study highlights the toxic effects of $\mathrm{AlCl}$ and $\mathrm{NaF}$ intake with drinking water during the prenatal and early postnatal stages of life, and the possible alterations in the brain monoamines contents and AChE activity. The results of the present study were quantitatively different

Table 3 The exploratory learning (time spent touching the object) in male offspring of groups I to VII, 70 days postnatal. Data are presented as a mean of eight rats \pm SEM

\begin{tabular}{|c|c|c|c|c|c|}
\hline \multirow{2}{*}{$\begin{array}{l}\text { Experimental } \\
\text { groups }\end{array}$} & \multicolumn{5}{|c|}{ Time spent touching the object (min) } \\
\hline & 1 day & 2 days & 3 days & 4 days & 5 days \\
\hline Group I & $1.44 \pm 0.06$ & $0.92 \pm 0.05$ & $0.86 \pm 0.02$ & $0.82 \pm 0.02$ & $0.796 \pm 0.025$ \\
\hline Group ॥ & $0.83 \pm 0.02^{\mathrm{a}}$ & $0.77 \pm 0.02^{\mathrm{a}}$ & $0.74 \pm 0.03^{\mathrm{a}}$ & $0.7 \pm 0.03^{\mathrm{a}}$ & $0.67 \pm 0.026^{a}$ \\
\hline Group III & $1.48 \pm 0.03^{b}$ & $0.85 \pm 0.02$ & $0.83 \pm 0.02^{b}$ & $0.79 \pm 0.02^{b}$ & $0.76 \pm 0.18^{b}$ \\
\hline Group IV & $0.748 \pm 0.03^{\mathrm{ac}}$ & $0.67 \pm 0.02^{\mathrm{abc}}$ & $0.63 \pm 0.02^{\mathrm{abc}}$ & $0.596 \pm 0.02^{\mathrm{abc}}$ & $0.58 \pm 0.021^{\mathrm{abc}}$ \\
\hline Group V & $1.36 \pm 0.34^{\mathrm{bcd}}$ & $0.96 \pm 0.02^{\mathrm{bcd}}$ & $0.88 \pm 0.02^{\mathrm{bd}}$ & $0.84 \pm 0.02^{\mathrm{bd}}$ & $0.81 \pm 0 . .019^{b d}$ \\
\hline Group VI & $0.61 \pm 0.03^{\mathrm{abcde}}$ & $0.61 \pm 0.03^{\mathrm{abce}}$ & $0.56 \pm 0.03^{\text {abcde }}$ & $0.52 \pm 0.03^{\mathrm{abcde}}$ & $0.495 \pm 0.02^{\mathrm{abcde}}$ \\
\hline Group VII & $1.56 \pm 0.05^{\mathrm{abdef}}$ & $1.007 \pm 0.06^{\mathrm{bcdf}}$ & $0.878 \pm 0.04^{\text {bdf }}$ & $0.846 \pm 0.02^{\mathrm{bdf}}$ & $0.79 \pm 0.021^{\text {bdf }}$ \\
\hline
\end{tabular}

a, b, c, d, e, f: Significant difference in comparison with the group I, II, III, IV, V, VI, and VII, at $\mathrm{a}=0.05(P<0.05)$, respectively 
Table 4 The levels of monoamines $(\mu \mathrm{g} / \mathrm{g})$ in the cerebral cortex of male offspring in groups I to VII, 70 days postnatal. Data were presented as a mean of eight rats \pm SEM

\begin{tabular}{|c|c|c|c|c|}
\hline Experimental. groups & Norepinephrine & Epinephrine & Dopamine & Serotonin \\
\hline Group I & $0.499 \pm 0.12$ & $0.57 \pm 0.027$ & $0.4 \pm 0.015$ & $0.37 \pm 0.019$ \\
\hline Group II & $0.55 \pm 0.028$ & $0.49 \pm 0.022$ & $0.37 \pm 0.01$ & $0.33 \pm 0.016^{a}$ \\
\hline Group III & $0.57 \pm 0.02$ & $0.55 \pm 0.014$ & $0.33 \pm 0.02$ & $0.36 \pm 0.01$ \\
\hline Group IV & $0.64 \pm 0.04^{\mathrm{ab}}$ & $0.64 \pm 0.014^{\text {bca }}$ & $0.48 \pm 0.013^{\mathrm{abc}}$ & $0.27 \pm 0.004^{\mathrm{abc}}$ \\
\hline Group V & $0.50 \pm 0.021^{d}$ & $0.62 \pm 0.02^{\mathrm{bc}}$ & $0.4 \pm 0.016^{d}$ & $0.28 \pm 0.01^{\mathrm{abc}}$ \\
\hline Group VI & $0.63 \pm 0.035^{\text {abe }}$ & $0.45 \pm 0.034^{\text {acde }}$ & $0.8 \pm 0.02^{\mathrm{abcde}}$ & $0.241 \pm 0.01^{\text {abce }}$ \\
\hline Group VII & $0.47 \pm 0.017^{\mathrm{fdcb}}$ & $0.49 \pm 0.027^{\text {cdea }}$ & $0.72 \pm 0.055^{\text {abcdef }}$ & $0.305 \pm 0.014^{\text {acf }}$ \\
\hline
\end{tabular}

a, b, c, d, e, f: Significant difference in comparison with the group I, II, III, IV, V, VI, and VII, at a $=0.05(P<0.05)$, respectively

according to the brain region. The alterations in the brain monoamine transmission observed herein were not surprising, because the prenatal life, particularly the third trimester of pregnancy, is an extremely critical period of brain development. During this period, establishment of brain connections and synaptogenesis unfold, a process in which monoaminergic and cholinergic systems play a central role. Monoamines are expressed in the very early embryonic stages (Herlenius \& Lagercrantz, 2004; Slotkin, Lappi, McCook, Tayyeb, Eylers, \& Seidler, 1994). It is thought that infants might be at particular risk of $\mathrm{Al}$ toxicity because of the immaturity of the blood-brain barrier, the gut, and renal system (Bishop, Morley, Chir, Day, \& Lucas, 1997).

In the present investigation, the offspring exposed to $\mathrm{Al}$ and $\mathrm{NaF}$ alone or in combination during the prenatal and postnatal life had lower dopamine (DA) and serotonin (5-HT) contents in the hippocampus and hypothalamus; these results were concomitant with an increase in hippocampal norepinephrine. Similar results appeared in the hypothalamus. The cerebral serotonin was also reduced in all treated groups, but dopamine was elevated in the cerebral cortex of the rat offspring exposed to aluminum alone or combination with sodium fluoride. These results may be explained by delay in the neuro-maturation of the monoaminergic systems and/or imbalance between the synthesis and degradation of these monoamines (El-Habibi, Mousa, \& Mohamed,
2011; Pereira, Dombrowski, Losso, Chioca, Da Cunha, \& Andreatini, 2011). It has been shown that exposure to aluminum/sodium fluoride during the gestational and lactational periods induced persistent neurobehavioral deficits in the offspring due to the ability of aluminum and fluoride to transport through the placental barrier and to cross the blood-brain barrier (Dec et al., 2017; Panchal \& Verma, 2014; World Health Organization, 1996). Moreover, fluorine was found to induce deregulation in the secretion of serotonin, dopamine, norepinephrine, acetylcholine, and epinephrine in the hippocampus, striatum, and cerebral cortex (Dec et al., 2017). In this regard, it was reported that the potential implications of aluminum in the etiopathogenesis of neurological disorders were attributed, at least in part, to its inhibitory effect on the activity of dopamine-beta-hydroxylase (Milanese, Lkhayat, \& Zatta, 2001). Similar inference was raised earlier by Zheng and Liang (1998) who suggested that the suppression of the dopaminergic transmission in the central nervous system might play an important role in Al-induced neurotoxicity. The present study revealed a significant elevation in the norepinephrine brain content in the rats born to Al-exposed mothers or the offspring that were persistently exposed to $\mathrm{AlCl}_{3}$ from the postnatal period until day 70. This increase might have been caused by the stress in forced by $\mathrm{Al}$ metal toxicity which triggered the activation of NE synthetic pathway, particularly the step which involved the conversion of dopamine to NE via

Table 5 The levels of monoamines $(\mu \mathrm{g} / \mathrm{g})$ in hippocampus of male offspring in groups I to VII, 70 days postnatal. Data were presented as a mean of eight rats \pm SEM

\begin{tabular}{lllll}
\hline Experimental. groups & Norepinephrine & Epinephrine & Dopamine & Serotonin \\
\hline Group I & $0.32 \pm 0.014$ & $0.27 \pm 0.011$ & $0.42 \pm 0.027$ & $0.17 \pm 0.01$ \\
Group II & $0.59 \pm 0.011^{\mathrm{a}}$ & $0.314 \pm 0.012$ & $0.26 \pm 0.007^{\mathrm{a}}$ & $0.15 \pm 0.05^{\mathrm{a}}$ \\
Group III & $0.61 \pm 0.011^{\mathrm{a}}$ & $0.296 \pm 0.024$ & $0.38 \pm 0.013^{\mathrm{ab}}$ & $0.167 \pm 0.06$ \\
Group IV & $0.56 \pm 0.016^{\mathrm{a}}$ & $0.328 \pm 0.018^{\mathrm{a}}$ & $0.284 \pm 0.01^{\mathrm{ac}}$ & $0.139 \pm 0.004^{\mathrm{ac}}$ \\
Group V & $0.39 \pm 0.018^{\mathrm{abcd}}$ & $0.27 \pm 0.011^{\mathrm{bd}}$ & $0.27 \pm 0.022^{\mathrm{ac}}$ & $0.149 \pm 0.01^{\mathrm{ac}}$ \\
Group VI & $0.55 \pm 0.04^{\mathrm{ae}}$ & $0.40 \pm 0.0113^{\mathrm{abcde}}$ & $0.254 \pm 0.01^{\mathrm{ac}}$ & $0.13 \pm 0.007^{\mathrm{ac}}$ \\
Group VII & $0.49 \pm 0.028^{\text {fecdba }}$ & $0.34 \pm 0.014^{\mathrm{acef}}$ & $0.24 \pm 0.007^{\mathrm{acd}}$ & $0.129 \pm 0.004^{\mathrm{ceab}}$ \\
\hline
\end{tabular}

a, b, c, d, e, f: Significant difference in comparison with the group I, II, III, IV, V, VI, and VII, at $\mathrm{a}=0.05(P<0.05)$, respectively 
Table 6 The levels of monoamines $(\mu \mathrm{g} / \mathrm{g})$ in hypothalamus of male offspring in groups I to VII, 70 days postnatal. Data were presented as a mean of eight rats \pm SEM

\begin{tabular}{|c|c|c|c|c|}
\hline Experimental. groups & Norepinephrine & Epinephrine & Dopamine & Serotonin \\
\hline Group I & $1.07 \pm 0.06$ & $0.185 \pm 1.3$ & $0.899 \pm 0.01$ & $0.884 \pm 0.047$ \\
\hline Group II & $0.682 \pm 0.013^{\mathrm{a}}$ & $1.24 \pm 0.046$ & $0.435 \pm 0.04^{a}$ & $0.54 \pm 0.018^{\mathrm{a}}$ \\
\hline Group III & $1.15 \pm 0.046^{\mathrm{b}}$ & $1.29 \pm 0.14^{b}$ & $0.7 \pm 0.03^{\mathrm{ab}}$ & $0.81 \pm 0.01^{b}$ \\
\hline Group IV & $1.46 \pm 0.015^{\mathrm{abc}}$ & $1.75 \pm 0.07^{\mathrm{abc}}$ & $0.5 \pm 0.003^{\mathrm{ac}}$ & $0.68 \pm 0.036^{\mathrm{abc}}$ \\
\hline Group V & $1.37 \pm 0.019^{a b c}$ & $1.2 \pm 0.04^{\mathrm{bd}}$ & $0.78 \pm 0.009^{\mathrm{abcd}}$ & $0.926 \pm 0.048^{b c d}$ \\
\hline Group VI & $1.31 \pm 0.011^{\mathrm{ab}}$ & $1.82 \pm 0.199^{\text {abce }}$ & $0.486 \pm 0.03^{\text {ace }}$ & $0.565 \pm 0.028^{\text {acde }}$ \\
\hline Group VII & $1.24 \pm 0.07^{\mathrm{abd}}$ & $1.48 \pm 0.11^{f}$ & $0.77 \pm 0.014^{\mathrm{abdf}}$ & $0.638 \pm 0.012^{\text {ceab }}$ \\
\hline
\end{tabular}

a, b, c, d, e, f: Significant difference in comparison with the group I, II, III, IV, V, VI, and VII, at a $=0.05(P<0.05)$, respectively

hydroxylation. In this regard, it was reported that when the sympathetic neuronal activity was stimulated under stressful conditions for a prolonged period of time, the amounts of mRNA coding for tyrosine hydroxylase $(\mathrm{TH})$, the rate-limiting enzyme, are increased in the neuronal perikarya, thereby increasing the biosynthesis of norepinephrine (George \& Siegel, 1999).

In the cerebral cortex, hippocampus, and hypothalamus, AChE activity was reduced in the group exposed to long-term intake of $\mathrm{NaF}$ or $\mathrm{AlCl} 3$ alone or in combination from prenatal day 6 until postnatal day 70 . Also, a decrease in AChE activity was observed in the hypothalamus, in the groups exposed to $\mathrm{AlCl} 3$ alone or co-administered with $\mathrm{NaF}$ for less duration, which may indicate that for the $\mathrm{Al}$ and $\mathrm{F}$ to induce their effects, an extended exposure is not a crucial prerequisite. AChE activity is important to maintain normal brain physiological functions and essential in the learning and memory processing (Shalini \& Sharma, 2015). The enzyme inactivation leads to the accumulation of acetylcholine that might alter the synaptic transmission of impulses and weaken the CNS coordination of the sensory, motor, and cognitive functions (Čolović, Krstić, Lazarević-Pašti, Bondžić, \& Vasić, 2013). Aluminum and fluoride have been reported to exert an inhibitory effect on $\mathrm{AChE}$

Table 7 The activities of acetylcholinesterase ( $\mu \mathrm{mol} \mathrm{SH} / \mathrm{g} / \mathrm{min}$ ) in the cerebral cortex, hippocampus, and hypothalamus of male offspring in groups I to VII, 70 days postnatal. Data were presented as a mean of eight rats \pm SEM

\begin{tabular}{llll}
\hline Experimental. groups & Cerebral cortex & Hippocampus & Hypothalamus \\
\hline Group I & $14.5 \pm 0.33$ & $18.25 \pm 0.45$ & $17.62 \pm 0.596$ \\
Group II & $12.37 \pm 0.42^{\mathrm{a}}$ & $12.25 \pm 0.45^{\mathrm{a}}$ & $12.37 \pm 0.625^{\mathrm{a}}$ \\
Group III & $13.37 \pm 0.6$ & $17 \pm 0.42^{\mathrm{b}}$ & $17.51 \pm 0.41^{\mathrm{b}}$ \\
Group IV & $11.75 \pm 0.37^{\mathrm{ac}}$ & $12.50 \pm 0.78^{\mathrm{ac}}$ & $12.93 \pm 0.40^{\mathrm{ac}}$ \\
Group V & $15.12 \pm 0.4^{\mathrm{bcd}}$ & $18.12 \pm 0.44^{\mathrm{bd}}$ & $14.54 \pm 0.279^{\mathrm{abcd}}$ \\
Group VI & $11 \pm 0.33^{\mathrm{abce}}$ & $13.25 \pm 0.59^{\mathrm{ace}}$ & $12 \pm 0.36^{\mathrm{ace}}$ \\
Group VII & $15.12 \pm 0.40^{\mathrm{bcdf}}$ & $18 \pm 0.46^{\mathrm{bdf}}$ & $15.14 \pm 0.29^{\mathrm{abcdf}}$ \\
\hline a, b, c, d, e, f. Significant differ &
\end{tabular}

$\mathrm{a}, \mathrm{b}, \mathrm{c}, \mathrm{d}, \mathrm{e}, \mathrm{f}$ : Significant difference in comparison with the group I, II, III, IV, V, VI, and $\mathrm{VII}$, at $\alpha=0.05(P<0.05)$, respectively activity (Lakshmi, Sudhakar, \& Anisha, 2014; Shalini \& Sharma, 2015). The mechanism by which Al decreased the AChE activity was thought to be due to the attachment of aluminum to the $\mathrm{SH}$ groups of the enzyme at its active sites, thus preventing the binding of the substrates and inhibiting the reactions catalyzed by the enzyme (Zaman, Zaman, \& Siddique, 1993; Zheng \& Liang, 1998). Moreover, it was reported that $\mathrm{Al}$ interfered with the metabolism of acetyl Co-A, which would reduce the formation of acetylcholine, and hence, the substrate for the AChE activity (Ravi et al., 2000; Szutowicz, Bielarczyk, Jankowska-Kulawy, Pawełczyk, \& Ronowska, 2013).

Exploratory behavior is widely used to assess cognitive functions and spatial learning capabilities in rodents. The results of the open field test revealed that the rats exposed to $\mathrm{Al}$ and $\mathrm{NaF}$ alone or $\mathrm{Al} / \mathrm{NaF}$ during the prenatal period up to day 70 of postnatal stages showed a decrease in their exploratory behavior and failed to habituate to strange objective or novel environment in the five consecutive days in comparison with the corresponding control or the groups that were exposed only up to the end of the weaning period. These findings are in agreement with previous studies which described similar effects on the open field parameters (Kinawy \& Al-Eidan, 2018; Liu et al., 2014; Nallagouni, Mesram, \& Karnati, 2018). The explanation of the open field outcomes is quite possible in the light of the present results which revealed profound perturbations in the brain monoamine neurotransmission and $\mathrm{AChE}$ activity which would interfere with the cognitive and sensory-motor capabilities and consequently hindering the neural activities required for the environmental exploration and coping with unfamiliar stimuli.

\section{Conclusion}

Administration of sodium fluoride and aluminum chloride separately or conjointly during the early stages of life induced explicit, persistent, and irreversible signs of impairment in the monoamines homeostasis, acetylcholinesterase activity, and the ability of the offspring to set the proper neural adjustments required to cope with unfamiliar stimuli. 


\section{Abbreviations}

5HT: Serotonin; AChE: Acetylcholinesterase; DA: Dopamine; E: Epinephrine; NE: Norepinephrine

\section{Acknowledgements}

There is no acknowledgment.

\section{Funding}

Not funded.

\section{Availability of data and materials}

The data are available from the author.

\section{Authors' contributions}

Single author. The author read and approved the final manuscript.

\section{Ethics approval}

Animals were maintained at the College of Science, Dammam University, animal house, where handling and use of the animals were strictly in agreement with the regulations and guidelines on the practice embraced by the ethics committees for use of animals for research.

\section{Consent for publication}

Not applicable.

\section{Competing interests}

The author declares that she has no competing interests.

\section{Publisher's Note}

Springer Nature remains neutral with regard to jurisdictional claims in published maps and institutional affiliations.

\section{Received: 31 October 2018 Accepted: 22 February 2019}

Published online: 06 March 2019

\section{References}

Abu-Taweel, G. M., Ajarem, J. S., \& Ahmad, M. (2012). Neurobehavioral toxic effects of perinatal oral exposure to aluminum on the developmental motor reflexes, learning, memory and brain neurotransmitters of mice offspring. Pharmacology, Biochemistry, and Behavior, 101(1), 49-56.

Aitken, P. P. (1974). Early experience, emotionality, and exploration in the rat: Denenperg's hypothesis. Developmental Psychobiology, 7, 129-134.

Akinrinade, I. D., Memudu, A. E., \& Ogundele, O. M. (2015). Fluoride and aluminium disturb neuronal morphology, transport functions, cholinesterase, lysosomal and cell cycle activities. Pathophysiology, 22(2), 05-15.

Belojevic, G., \& Jakovljevic, B. (1998). Aluminum and Alzheimer's disease. Srpsk Arhiv za Celokupno Lekarstvo, 126, 283-289.

Bishop, N. J., Morley, R., Chir, B., Day, J. P. \& Lucas, A. (1997). Aluminum neurotoxicity in preterm infants receiving intravenous feeding solutions. The New England Journal of Medicine, 336, 1557-1561.

Burke, W. J., Li, S. W., Chung, H. D., Ruggiero, D. A., Kristal, B. S., Johnson, E. M., et al. (2004). Neurotoxicity of MAO metabolites of catecholamine neurotransmitters: role in neurodegenerative diseases. Neurotoxicology, 25, $101-115$

Choi, A. L., Sun, G., Zhang, Y., \& Grandjean, P. (2012). Developmental fluoride neurotoxicity: a systematic review and meta-analysis. Environmental Health Perspectives, 120(10), 1362-1368.

Čolović, M. B., Krstić, D. Z., Lazarević-Pašti, T. D., Bondžić, A. M., \& Vasić, V. M. (2013). Acetylcholinesterase inhibitors: pharmacology and toxicology. Current Neuropharmacology, 11(3), 315-335.

Dec, K., Łukomska, A., Maciejewska, D., Jakubczyk, K., Baranowska-Bosiacka, I., Chlubek, D., ... Gutowska, I. (2017). The influence of fluorine on the disturbances of homeostasis in the central nervous system. Biological Trace Element Research, 177, 224-234.

Domingo, J. L., Llorens, J., Sanchez, D. J., Gomez, M., Llobet, J. M., \& Corbella, J. (1996). Age related effects of aluminum ingestion on brain aluminum accumulation and behaviour in rats. Life Sciences, 58(17), 1387-1395.

Dórea, J. G. (2015). Exposure to mercury and aluminum in early life: developmental vulnerability as a modifying factor in neurologic and immunologic effects. International Journal of Environmental Research and Public Health, 12(2), 1295-1313.
El-Habibi, E. M. I., Mousa, A. T., \& Mohamed, E. W. (2011). Perturbation of brain neurotransmitters by aluminium in male rats and the potential role of sage, Egypt. The Journal of Experimental Biology (Zoology), 7(2), 249-259.

Fan, Z., Gao, Y., Wang, W., Gong, H., Guo, M., Zhao, S., et al. (2016). Prevalence of brick tea-type fluorosis in the Tibet autonomous region. Journal of Epidemiology, 26, 57-63.

Fulton, B., \& Jeffery, E. H. (1990). Absorption and retention of aluminum from drinking water: effect of citric and ascorbic acids on aluminum tissue levels in rabbits. Fundamental and Applied Toxicology, 14(4), 788-796.

Ge, Q., Xie, C., Zhang, H., Tan, Y., Wan, C., Wang, W., \& Jin, T. (2018). Differential expression of miRNAs in the hippocampi of offspring rats exposed to fluorine combined with aluminum during the embryonic stage and into adulthood. Biological Trace Element Research. https://doi.org/10.1007/s12011018-1445-4.

George, J., \& Siegel, M. D. (1999). Basic neurochemistry: molecular, cellular and medical aspects, (6th ed., ). U.S.A.: Williams, L and Wilkins.

Golub, M. S., \& Domingo, J. L. (1997). What we know and what we need to known about development aluminum toxicity. In R. A. Yokel, \& M. S. Golub (Eds.), Research issues in aluminum toxicity, chapter 8, (pp. 151-163). Washington, D.C.: Taylor and Francis

Grima, G., Benz, B., Parpura, V., Cuénod, M.. \& Do, K. Q. (2003). Dopamine-induced oxidative stress in neurons with glutathione deficit: implication for schizophrenia. Schizophrenia Research, 62, 213-224.

Harkness, J. E., \& Wagner, J. E. (1983). Biology and husbandy. In The biology and medicine of rabbits and rodents, (2nd ed., pp. 36-51). Lea and Feiger.

He, L., \& Chen, J. (2006). DNA damage, apoptosis and cell cycle changes induced by fluoride in rat oral mucosal cells and hepatocytes. World Journal of Gastroenterology, 12(7), 1144-1148.

Herlenius, E., \& Lagercrantz, H. (2004). Development of neurotransmitter systems during critical periods. Experimental Neurology, 190(1), 8-21.

Kaur, T., Bijarnia, R. K., \& Nehru, B. (2009). Effect of concurrent chronic exposure of fluoride and aluminum on rat brain. Drug and Chemical Toxicology, 32(3), 215-221.

Kinawy, A. A., \& Al-Eidan, A. A. (2018). Impact of prenatal and postnatal treatment of sodium fluoride and aluminum chloride on some hormonal and sensorimotor aspects in rats. Biological Trace Element Research. https://doi. org/10.1007/s12011-018-1311-4

Kinawy, A. A., \& Ezzat, A. R. (2013). Impact of aluminum and antioxidants on some neural aspects. Riga: Lambert Academic Publishing.

Kovarik, Z., Radić, Z., Berman, H. A., Simeon-Rudolf, V., Reiner, E., \& Taylor, P. (2003). Acetylcholinesterase active centre and gorge conformations analysed by combinatorial mutations and enantiomeric phosphonates. Biochemical Journal, 373, 33-40.

Kraus, A. S., \& Forbes, W. F. (1992). Aluminum, fluoride and the prevention of Alzheimer's disease. Canadian Journal of Public Health, 83, 97-100.

Kumar, S. (2002). Aluminum-induced changes in the rat brain serotonin system. Food and Chemical Toxicology, 40, 1875-1880.

Lakshmi, B. V. S., Sudhakar, M., \& Anisha, M. (2014). Neuroprotective role of hydroalcoholic extract of Vitis vinifera against aluminum-induced oxidative stress in rat brain. NeuroToxicology, 41, 73-79.

Liu, F., Ma, J., Zhang, H., Liu, P., Liu, Y. P., Xing, B., \& Dang, Y. H. (2014). Fluoride exposure during development affects both cognition and emotion in mice. Physiology \& Behavior, 30(124), 1-7.

Milanese, M., Lkhayat, M. I., \& Zatta, P. (2001). Inhibitory effect of aluminum on dopamine beta- hydroxylase from bovine adrenal gland. Journal of Trace Elements in Medicine and Biology, 15(2-3), 139-141.

Nallagouni, C. S. R., Mesram, N., \& Karnati, P. R. (2018). Amelioration of aluminumand fluoride-induced behavioral alterations through resveratrol in rats. Asian Journal of Pharmaceutical and Clinical Research, 11(1), 289-293.

Pagel, P., Blome, J., \& Wolf, H. U. (2000). High-performance liquid chromatographic separation and measurement of various biogenic compounds possibly involved in the pathomechanism of Parkinson's disease. Journal of Chromatography B, 746, 297-304

Panchal, S., \& Verma, R. J. (2014). Effect of sodium fluoride in maternal and offspring rats and its amelioration. Asian Pacific Journal of Reproduction, 3(1), $71-76$

Pereira, M., Dombrowski, P. A., Losso, E. M., Chioca, L. R., Da Cunha, C., \& Andreatini, R. (2011). Memory impairment induced by sodium fluoride is associated with changes in brain monoamine levels. Neurotoxicity Research, 19(1), 55-62.

Ravi, S. M. Prabhu, B. M. Raju, T. R, \& Bindu, P. N. (2000). Long term effects of post natal aluminum exposure on acetylcholinesterase activity and biogenic 
amine neurotransmitters in rat brain. Indian Journal of Physiology and Pharmacology, 4, 473-478.

Saunders, N. R., Liddelow, S. A., \& Dziegielewska, K. M. (2012). Barrier mechanisms in the developing brain. Frontiers in Pharmacology, 3, 46.

Shalini, B., \& Sharma, J. D. (2015). Beneficial effects of emblica officinalis on fluoride-induced toxicity on brain biochemical indexes and learning-memory in rats. Toxicology International, 22(1), 35-39.

Slotkin, T. A., Lappi, E. C., McCook, E. C., Tayyeb, M. I., Eylers, J. P., \& Seidler, F. J. (1994). Glucocorticoids and the development of neuronal function: effect of prenatal dexamethasone exposure on central noradrenergic activity. Biology of the Neonate, 61, 356-336.

Strunecká, A. (1999). Aluminum plus fluoride: a new, deadly duo in AD. The News in Dementia, 1, 2-3.

Szutowicz, A., Bielarczyk, H., Jankowska-Kulawy, A., Pawełczyk, T., \& Ronowska, A. (2013). Acetyl-CoA the key factor for survival or death of cholinergic neurons in course of neurodegenerative diseases. Neurochemical Research, 38(8), 1523-1542.

Taïr, K., Kharoubi, O., Taïr, O. A., Hellal, N., \& Benyettou, I. (2016). Aluminuminduced acute neurotoxicity in rats: treatment with aqueous extract of Arthrophytum (Hammada scoparia). Journal of Acute Disease, 5(6), 470-482.

Thirunavukkarasu, S. V., Venkataraman, S., Raja, S., \& Upadhyay, L. (2012). Neuroprotective effect of Manasamitra vatakamagainst aluminum induced cognitive impairment and oxidative damage in the cortex and hippocampus of rat brain. Drug and Chemical Toxicology, 35(1), 104-115.

Varner, J. A., Jensen, K. F., Horvath, W., \& Isaacson, R. L. (1998). Chronic administration of aluminum-fluoride or sodium-fluoride to rats in drinking water: alterations in neuronal and cerebrovascular integrity. Brain Research, 78(1-2), 284-298

World Health Organization (1996). Trace elements in human nutrition and health. Geneva: World Health Organization.

Xiang, Q., Liang, Y., Chen, L., Wang, C., Chen, B., Chen, X., et al. (2003). Effect of fluoride in drinking water on children's intelligence. Fluoride, 36, 84-94.

Yazdi, S. M., Sharifian, A., Dehghani-Beshne, M., Momeni, V. R., \& Aminian, O. (2011). Effects of fluoride on psychomotor performance and memory of aluminum potroom workers. Fluoride, 44(3), 158-162.

Yellamma, K., Saraswathamma, S., \& Kumari, B. N. (2010). Cholinergic system under aluminum toxicity in rat brain. Toxicology International, 17(2), 106-112.

Zaman, K., Zaman, W., \& Siddique, H. (1993). Haematological and enzymatic results of aluminum intoxication in rats. Comparative Biochemistry and Physiology Part C: Comparative Pharmacology, 105, 73-76.

Zatta, P., Ibn-Lkhayat-Idrissi, M., Zambenedetti, P., Kilyen, M., \& Kiss, T. (2002). In vivo and in vitro effects of aluminum on the activity of mouse brain acetylcholinesterase. Brain Research Bulletin, 59, 41-45.

Zheng, Y. X., \& Liang, Y. X. (1998). The antagonistic effects of L-dopa and eserine on Al-induced neurobehavioral deficits in rats. Biomedical and Environmental Sciences, 11(4), 321-330.

Zhu, M., Huang, C., Ma, X., Wu, R., ZhuW, L. X., Liang, Z., ... Zhong, C. (2016). Modulation of miR-19 in aluminum-induced neural cell apoptosis. Journal of Alzheimer's Disease, 50, 1149-1162.

\section{Submit your manuscript to a SpringerOpen ${ }^{\circ}$ journal and benefit from:}

- Convenient online submission

- Rigorous peer review

- Open access: articles freely available online

- High visibility within the field

- Retaining the copyright to your article

Submit your next manuscript at $\boldsymbol{\nabla}$ springeropen.com 